\title{
Determination of Stem Rust Ug99Disease Severity in Selected Wheat Backcrosses in Kenya
}

\author{
Tubei E. Jackline ${ }^{1}$, Omwoyo Ombori ${ }^{1}$, Peter N. Njau ${ }^{2}$, Fredrick M. Njoka ${ }^{3}$ \\ ${ }^{I}$ Department of Plant Sciences, Kenyatta University P.O.Box 43844, Nairobi, \\ ${ }^{2}$ Kenya Agricultural and Livestock Research Organization, Njoro. \\ ${ }^{3}$ Department of Agricultural Resource Management, University of Embu, P.O.Box 6-60100 Embu. Kenya.
}

\begin{abstract}
Stem rust(Pucciniagraministritici) is a disease of economic importance in wheat (Triticumaestivum L.) worldwide. The objective of this study was to determine the disease severity of the $B C_{l} F_{1}$ plants in the nursery at Kenya Agricultural and Livestock Research Organization, Njoro. Kingbird (resistant)

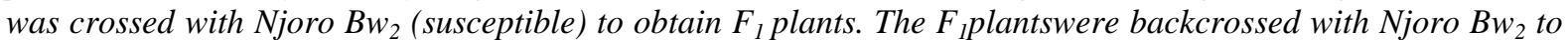
obtain a $B C_{1} F_{1}$ progeny. Two hundred and forty seeds of the $B C_{1} F_{1}$ plants, twenty eight resistant and susceptible parents were planted in two replicates and the Modified Cobb's Scale was used to record their disease severity scores. An excel work sheet programmed with the AUDPC formula was used to compute the Area Under Disease Progress Curve (AUDPC) values for $B C_{l} F_{l}$ plants. Variation of the disease severity scores and mean AUDPC among the wheat plants was analysed using Analysis of variance (ANOVA). Results showed 47.9\% ofresistant plants that portrayed the pseudo black chaff $(P B C)$ trait had low disease severity mean scores ranging from 0 to 1.0414 with mean AUDPC values below 99.8. The resistant plants without PBC were $43.3 \%$ and had disease severity mean score ranging from 0.9098 to 1.3686 with mean AUDPC values ranging from 99.8 to 260.The $B C_{1} F_{1}$ plants that showed susceptibility to stem rust disease were 21 (8.8\%) and had the highest disease severity mean score ranging from 1.3223 to 1.4914 with the highest mean AUDPC values ranging from 282.5 to 431.3. The ANOVA computation showed that, variation in the disease severity and in the mean AUDPC values among the individual plants $(P<0.001)$ was significant, but variation in mean AUDPC values from one replicate to another $(P>0.001)$ was not significant. The $B C_{l} F_{l}$ wheat plants showed a low disease severity score in the field indicating that these plants received the APR genes for stem rust and this could be useful for wheat improvement through breeding.
\end{abstract}

Key words:Stem rust, Ug99, resistance, backcross, improvement, disease severity

\section{Introduction}

Wheat (Triticum species) is one of the cereal grains known to have been domesticated first from the Middle East region and Ethiopian Highlands, but currently cultivated globally [1];[2]. The wild einkorn's wheat genetic study, suggests that it was first grown in the Karacadag Mountains in Southeastern Turkey [3]. Compared to other main cereals, wheat is the most significant source of carbohydrate in a majority of countries, and is the primary source of protein in human food as it has a higher protein content [4]. Flour for most baked products, beer and other alcoholic drinks are from the wheat grain [5];[6].

\subsection{Wheat Production Constraints}

Farmers and agricultural researchers face a major challenge of trying to develop and apply technology that can increase the global cereal yields enough for consumption, and use ways that are affordable, with minimum level of pollution to the environment [7]. Other than constraining factors like low soil fertility and drought, there are also biotic constraints comprising of weeds, insect attacks and diseases such as rusts, smuts, bunts, leaf blight, powdery mildew and head scab [8]. The most significant production challenges in most of the wheat growing areas are disease and particularly those triggered by the fungal pathogens and a few caused by viruses and bacteria [9]. Stem rust can cause up to 100\% loss [10] in the presence of susceptible host and favorable environmental conditions while leaf and stripe rust cause $60 \%$ loss of yield. Stem rust is the most limiting factor to wheat production [11];[12] due to its extensive distribution, its ability to mutate to new races and attack the previously resistant cultivars.

In 1998 stem rust caused by the fungus Pucciniagraministritici emerged in Uganda and was found on wheat lines well-known to have the stem rust resistance gene $\operatorname{Sr} 31$ (no virulence anywhere in the world had been reported on this gene) [13]. In 2005, a similar virulence was detected in Kenya and in Ethiopia [14], raising a major concern over the spread of race Ug99 across Africa, Asia and the Middle East[11]. As such, it is inevitable to produce varieties of wheat that can withstand Ug99 [15];[11]. 
The TTKSK (Ug99) is predicted to spread to the world's most important wheat growing regions in the near future [16]. Plant breeders and pathologists however, still have time to identify resistant genotypes, introgress the genes and increase the seed for farmers before the Ug99 causes a major problem in the Saudi Arabian Peninsula, South Asia and East Asia. This can reduce the devastating effect of the pathogen on susceptible cereals. Introgressing stem rust resistance genes into Njoro $\mathrm{Bw}_{2}$ variety, using the Kingbird variety derived from CIMMYT germplasm as the donor parent, might produce good results. The Kingbird variety has some adult plant resistance genes (non- race specific, polygenic genes) to Ug99 and matures early [17].Njoro $\mathrm{Bw}_{2}$ (recipient) is high yielding, drought resistant, has late maturity and is susceptible to Ug99 [18]. In order to cope with the rising rate of consumption, it is essential to breed for new high yielding cultivars, tolerant against biotic and abiotic stresses to ensure food security and to meet the challenges of the 21st century [16].

The main objective of this work was to determine the disease severity of the $\mathrm{BC}_{1} \mathrm{~F}_{1}$ plants in the nursery at Kenya Agricultural and Livestock Research Organization, Njoro.

\subsection{Experimental Site}

\section{Materials and Methods}

The field trials were carried out in a nursery, at Kenya Agricultural and Livestock Research Organization (KALRO) Njoro Centre, in Nakuru, Kenya from June 2012 to December, 2013. The experimental site is located at $0.3{ }^{0} \mathrm{~S}$ and $35.9{ }^{0} \mathrm{E}$ at $2185 \mathrm{~m}$ above sea level. The area has an average annual rainfall of $939 \mathrm{~mm}$ (average of 61 years) (Kenya Meteorological Station Identification Number 9031021) with an average daily minimum and maximum temperature of 9.7 and $23.5^{\circ} \mathrm{C}$ respectively.

\subsection{Plant Materials}

The seeds of the 'Kingbird' variety were obtained from CIMMYT and those of Njoro Bw 2 from KALRO, Njoro Centre. Njoro $\mathrm{Bw}_{2}$ wheat variety grown in Kenya is susceptible to Ug99 though it contains the $\mathrm{Sr} 2$ gene. Kingbird variety is resistant to stem rust and known to have the $S r 2$ gene with other slow rust resistant genes that form the "Sr2 complex" [19];[20].

\subsection{Experimental Design}

There were two blocks measuring $2 \mathrm{~m} \times 4.5 \mathrm{~m}$. The two blocks were each divided into two plots of $2 \mathrm{~m}$ $\times 2 \mathrm{~m}$ with $0.5 \mathrm{~m}$ wide alley-ways between the plots. These plots were used for planting the parents and the first filial generation $\left(F_{1}\right)$. There were five rows of each variety per plot, which were $0.4 \mathrm{~m}$ apart. There were two other plots of $6 \mathrm{~m} \times 6 \mathrm{~m}$ in the same nursery which were used for planting the $\mathrm{BC}_{1} \mathrm{~F}_{1}$ seeds in two replicates. The plots were made of twelve rows, $0.5 \mathrm{~m}$ apart. The experimental design was a randomized complete block design (RCBD).

\subsection{Field Practices}

The planting was carried out in June 2012, in long narrow furrows dug by hand a few inches (1-1.5 inches) deep to the ground, in the two plots of $2 \mathrm{~m} \times 2 \mathrm{~m}$ with $0.5 \mathrm{~m}$ wide alley-way in between. Seeds of Njoro $\mathrm{Bw}_{2}$ were planted in furrows made in plot one which had five rows that were $0.4 \mathrm{~m}$ apart. Two weeks later in plot two, the same was carried out for the seeds of Kingbird variety which is early maturing to synchronize flowering. During planting, the advised rate of Di-ammonium phosphate (DAP) was applied at 150 $\mathrm{kg} / \mathrm{ha}$, as the source of nitrogen and phosphorus (18:24). Two times between stem elongation and booting stages, weeding was carried out by hand.At flowering stage, hand emasculation was carried out on $\mathrm{Njoro} \mathrm{Bw}_{2}$ (female parent) two days before anthesis, to prepare for cross pollination with pollen from 'Kingbird' (donor parent) which was carrying the gene of interest. The highest and lowest florets of $\mathrm{NjoroBw}_{2}$ were clipped off leaving 4 florets per spikelet. Scissors were used to chop the top part and forceps were used to remove the anthers. This was immediately followed by bagging to prevent random pollination. Pollination bags were used for bagging where they were tied at the base of the inflorescence with a thread. After bagging, the emasculated flowers were tagged to avoid confusion. The tags were labelled to show date of emasculation, name of female and male plant. The date of pollination was indicated on the tag after pollination. Three days after emasculation, pollen from dehisced anthers of 'Kingbird' were collected and dusted onto the stigmas of emasculated flowers of 'Njoro $\mathrm{Bw}_{2}$ '. Bagging was carried out after pollination to prevent random pollination.After pollination, the seeds bagged with the pollination bags were allowed to ripen (develop, fill up, and become harder and drier) for six weeks, then the mature seeds were harvested to obtain the $F_{1}$ progeny (first filial generation). Harvesting was carried out by hand using a knife by snipping off the head from the stem. Each head was threshed separately and kernels stored in different medical envelopes. 


\subsection{Determination of Disease Severity in $\mathrm{BC}_{1} \mathrm{~F}_{1}$}

To obtain $\mathrm{BC}_{1} \mathrm{~F}_{1}$ seeds (backcross $\mathrm{F}_{1}$ seeds), a single backcross was made with Njoro $B \mathrm{w}_{2}$. At maturity, harvesting was carried out by cutting off the head from the stem. Each head was threshed separately and the kernels were stored in different envelopes.Based primarily on pustule size and the associated necrosis and chlorosis, the infection responses to rust infection were classified into four discrete categories: $\mathrm{R}=$ resistant, $\mathrm{MR}$ $=$ moderately resistant, $\mathrm{MS}=$ moderately susceptible and $\mathrm{S}=$ susceptible (large uredia) (Plate 1.) [21]. Infection responses that overlapped between MS and S categories were denoted as MSS (medium to large sized uredia without chlorosis or necrosis) and those that overlapped between MR and MS were denoted as M. The infection responses that overlapped between R and MR were denoted as RMR. The Pseudo black chaff (PBC) trait was also scored on the two hundred and forty plants and the parents. The plants which showed PBC were scored as $(+)$ while those without $\mathrm{PBC}$ were scored as (-).The evaluations for infection responses and stem rust severity were carried out on $17^{\text {th }}, 24^{\text {th }}$ and $31^{\text {st }}$ Dec. 2013 , respectively. The three scores that were obtained for each plant were used to determine the area under disease progress curve values (AUDPC) for each plant (see formula 1).

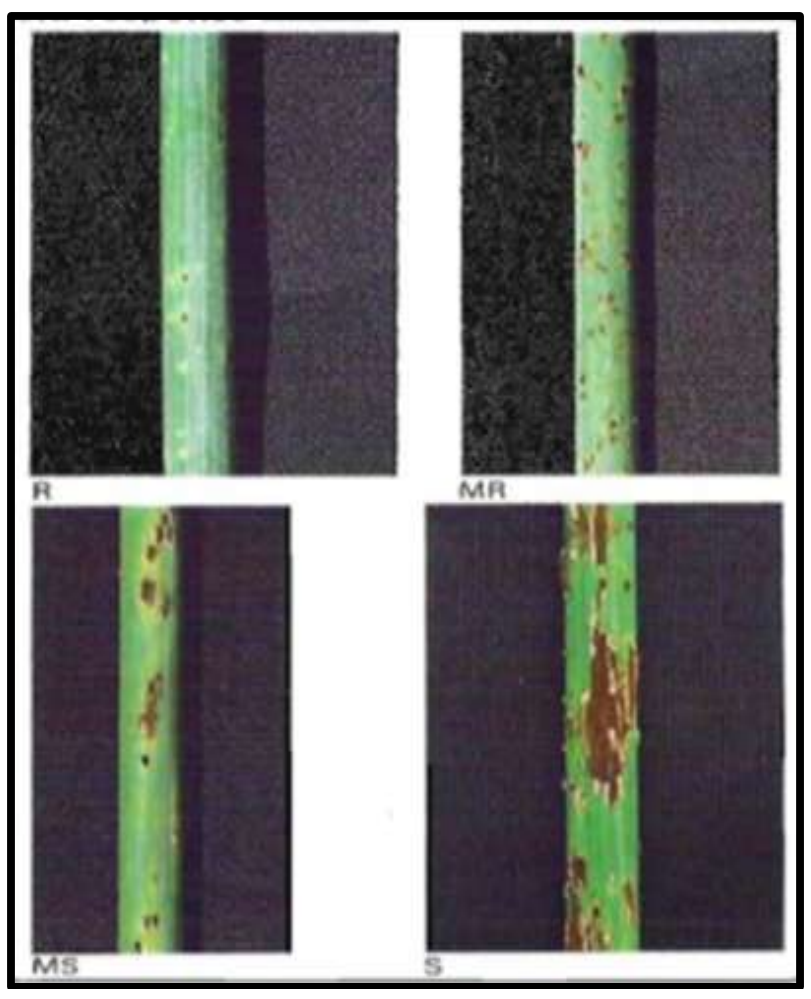

\subsection{DATA ANALYSIS}

The area under disease progress curve (AUDPC) was computed using the following formula:

(1) AUDPC $\left.\left.=\sum[\mathrm{t}) \mathrm{i}+1\right)-\mathrm{ti}[] \mathrm{y}(\mathrm{i}+1\}+\mathrm{iy}\right] / 2$ (http://www.apsnet.org.)

Where

it is the first assessment date of two consecutive assessment

iy is the disease severity on assessment date it

$t(i+1)$ is the second assessment date of two consecutive assessment

The disease severity scores of individual plants were transformed using $\log _{10}(X+1)$ for homogeneity. One wayANOVA was used to analyse data on disease severity and AUDPC among the wheat plants. Using the computer software SAS, the means were separated by use of the Honestly Significant Difference test (HSD at P < 0.05) (SAS Version 9.2, SAS Inc.) [22].

\subsection{Disease Severity of Adult Plants to Stem Rust Disease}

\section{Results and Discussion}

Assessment of adult plants on disease severity to stem rust categorized the $\mathrm{BC}_{1} \mathrm{~F}_{1}$ into three groups based on the final disease severity (FDS). There were 115 plants resistant to stem rust with pseudo black chaff (PBC) trait representing $47.9 \%$ of the total population, 104 wheat plants representing $43.3 \%$ of the total 
population, showed resistance to stem rust but did not express the PBC trait and $21(8.8 \%)$ plants that showed susceptibility to stem rust disease (Table 1.). The 115 resistant $\mathrm{BC}_{1} \mathrm{~F}_{1}$ plants and the resistant parent (Kingbird) which expressed the $\mathrm{PBC}$ trait, had low disease severity score with means ranging from 0 to 1.0441 in the final disease score $\left(3^{\text {rd }}\right.$ score). There were four plants $(76,81,134$ and 200) with PBC that had the lowest disease severity with mean of 0.1505 while plant 138 had disease severity mean of 0.00 (Table 1 ).

Table 1:Disease severity scores to Pucciniagraminissptritici race Ug99 among selected crosses

\begin{tabular}{|c|c|c|c|c|c|c|}
\hline \multicolumn{7}{|c|}{ Mean of Disease severity Score } \\
\hline Plant & $\begin{array}{l}1^{\text {st }} \\
\text { score (Trans) }\end{array}$ & $\begin{array}{l}2^{\text {nd }} \\
\text { score (Trans) }\end{array}$ & $\begin{array}{l}3^{\text {rd }} \\
\text { score (Trans) }\end{array}$ & IF type & PBC & $\begin{array}{l}\text { AUDPC } \\
\text { Means }\end{array}$ \\
\hline 138 & $0.00(0.0000)^{\mathrm{a}}$ & $0.00(0.0000)^{\mathrm{a}}$ & $0.00(0.0000)^{\mathrm{a}}$ & RMR & + & $0.0(0.0)^{\mathrm{a}}$ \\
\hline 76 & $0.00(0.0000)^{\mathrm{a}}$ & $0.50(0.1505)^{\mathrm{a}}$ & $0.50(0.1505)^{\mathrm{b}}$ & $\mathrm{R}$ & + & $7.0(2.1)^{b}$ \\
\hline 134 & $0.00(0.0000)^{\mathrm{a}}$ & $0.50(0.1505)^{\mathrm{a}}$ & $0.50(0.1505)^{b}$ & RMR & + & $7.0(2.1)^{b}$ \\
\hline 200 & $0.00(0.0000)^{\mathrm{a}}$ & $0.50(0.1505)^{\mathrm{a}}$ & $0.50(0.1505)^{b}$ & RMR & + & $7.0(2.1)^{b}$ \\
\hline 81 & $0.50(0.0000)^{\mathrm{a}}$ & $0.50(0.1505)^{\mathrm{a}}$ & $0.50(0.1505)^{b}$ & RMR & + & $7.0(2.1)^{b}$ \\
\hline 68 & $7.50(0.9098)^{b}$ & $12.50(1.1228)^{b}$ & $20.00(1.3096)^{\mathrm{c}}$ & $\mathrm{M}$ & - & $257.5(21.0)^{\mathrm{c}}$ \\
\hline 14 & $7.50(0.9098)^{b}$ & $12.50(1.1228)^{\mathrm{b}}$ & $20.00(1.3222)^{\mathrm{c}}$ & $\mathrm{M}$ & - & $257.5(21.1)^{\mathrm{c}}$ \\
\hline 27 & $7.50(0.9098)^{b}$ & $15.00(1.2041)^{\mathrm{c}}$ & $17.50(1.2632)^{\mathrm{c}}$ & $\mathrm{M}$ & - & $260.0(21.3)^{\mathrm{d}}$ \\
\hline 74 & $10.00(1.0414)^{\mathrm{c}}$ & $10.00(1.0414)^{\mathrm{d}}$ & $15.00(1.2041)^{d}$ & MS & - & $217.5(20.3)^{\mathrm{e}}$ \\
\hline 215 & $5.00(0.7782)^{b}$ & $10.00(1.0414)^{d}$ & $15.00(1.2041)^{\mathrm{c}}$ & MS & - & $195.0(19.1)^{f}$ \\
\hline 221 & $5.00(0.7782)^{b}$ & $10.00(1.0414)^{d}$ & $15.00(1.2041)^{\mathrm{c}}$ & MS & - & $95.0(19.1)^{\mathrm{f}}$ \\
\hline ****17 & $12.50(1.1228)^{d}$ & $22.50(1.3686)^{\mathrm{e}}$ & $27.50(1.4532)^{\mathrm{c}}$ & MS & - & $103.8(24.8)^{\mathrm{g}}$ \\
\hline$* * * 9$ & $15.00(1.2041)^{\mathrm{d}}$ & $22.50(1.3686)^{\mathrm{e}}$ & $30.00(1.4914)^{\mathrm{c}}$ & MSS & - & $431.3(25.4)^{\mathrm{h}}$ \\
\hline$* * * 25$ & $12.50(1.1228)^{d}$ & $20.00(1.3222)^{f}$ & $27.50(1.4532)^{\mathrm{c}}$ & MS & - & $385.0(24.4)^{\mathrm{g}}$ \\
\hline$* * 255$ & $10.00(1.0414)^{\mathrm{d}}$ & $10.00(1.0414)^{d}$ & $10.00(1.0414)^{\mathrm{d}}$ & MR & - & $185.0(19.3)^{f}$ \\
\hline$* * 266$ & $5.00(0.7782)^{\mathrm{b}}$ & $5.00(0.7782)^{\mathrm{g}}$ & $10.00(1.0414)^{\mathrm{d}}$ & MR & - & $125.0(16.1)^{\mathrm{h}}$ \\
\hline$* * 267$ & $10.00(1.0414)^{\mathrm{c}}$ & $10.00(1.0414)^{d}$ & $10.00(1.0414)^{b}$ & MR & - & $185.0(19.3)^{f}$ \\
\hline $\begin{array}{l}\text { P values } \\
\text { MSD }\end{array}$ & $\begin{array}{l}\mathrm{P}<0.0001 \\
0.7698\end{array}$ & & & & & \\
\hline
\end{tabular}

*Resistant parent (Kingbird); **Susceptible parent $\left(\mathrm{NJBW}_{2}\right) ; * * *$ Susceptible $\mathrm{BC}_{1} \mathrm{~F}_{1}$ plants; Trans, $\log _{10}(\mathrm{X}+1)$ transformed; (+), pseudo black chaff present (PBC); (-), pseudo black chaff absent; IF, Infection response; R, resistant; RMR, resistant to moderately resistant; MR, moderately resistant; MS, moderately susceptible; M, moderately resistant to moderately susceptible; MSS, moderately susceptible to susceptible; AUDPC, area under disease progress curve values are means of two replications and means with same letters within the column are not significantly different at $\mathrm{P}<0.05$ according to Tukey HSD test; means in parenthesis are transformed means of disease severity and AUDPC $\left(\log _{10}(\mathrm{X}+1)\right) ; 1^{\text {st }}, 2^{\text {nd }}$ and $3^{\text {rd }}$ score values are means of two replications; MSD, mean significance difference.

The final disease severity (FDS) mean scores of the 104 resistant plants without PBC ranged from 0. 9098 to 1.3686 which was slightly higher compared to the disease severity mean scores of the plants with PBC (Table 1.). Although all the resistant plants with and without $\mathrm{PBC}$ showed infection responses type R, MR and RMR, plants $(27,68$ and 14) with disease severity mean scores of 1.2632, 1.3096 and 1.3222 respectively, showed an intermediate (M) type of response to infection. Plants 74, 215 and 221 with a disease severity mean score of 1.2041 and plant 216 with a disease severity mean score of 1.1228 showed an MS response to infection though the disease severity was low (Table 1.).

The final mean disease severity scores for the 21 susceptible $\mathrm{BC}_{1} \mathrm{~F}_{1}$ plants was higher ranging from 1.3222 to 1.4914 . Plants 9,17 and 25 were the most susceptible with thehighest disease severitymeans of $1.4914,1.4532$ and 1.4532 respectively (Table 1.). Although all the $21 \mathrm{BC}_{1} \mathrm{~F}_{1}$ plants that showed susceptibility to stem rust had infection responses type MS and MSS , there were susceptible parent plants $\left(\mathrm{NJBW}_{2}\right)(255,266$ and 267) all with a disease severity mean score of 1.0414, which showed infection response type MR instead of the MS and MSS reaction expected in the susceptible plants (Table 1.). There was a significant difference in the disease severity mean scores between the plants $(\mathrm{P}<0.001)$.

\subsection{Stem Rust AUDPC Values of The $\mathrm{BC}_{1} \mathrm{~F}_{1}$ Wheat Plants and the Parents}

The area under disease progress curve (AUDPC) calculated, indicated that differences in the AUDPC means between the $240 \mathrm{BC}_{1} \mathrm{~F}_{1}$ plants with the parents was significant (Table 2.). All the 115 resistant $\mathrm{BC}_{1} \mathrm{~F}_{1}$ plants with the resistant parents which showed expression of PBC (+), had mean AUDPC values ranging from 0 to 151, with plants 76, 81, 134, and 200 showing the lowest mean AUDPC value of 7 (Table 2.). Plants that had no expression of PBC (-) had higher mean AUDPC values compared to plants that had the PBC. The lowest mean AUDPC values for the plants with no PBC was registered in plants 32 and 75 which was 99.8 followed by plants 88 and 206 which had a mean AUDPC value of 116. Plants without the PBC trait but with mean AUDPC values ranging from 99.8 to 195 showed higher resistance to stem rust as compared to plants with mean AUDPC values ranging from 217.5 to 260 (Table 2). 
Table 2: Pseudo black Chaff (PBC) response and area under disease progress curve AUDPC values

\begin{tabular}{|c|c|c|}
\hline Plant number & PBC & AUDPC values \\
\hline 76 & + & $7.0^{\mathrm{a}}$ \\
\hline 81 & + & $7.0^{\mathrm{a}}$ \\
\hline 134 & + & $7.0^{\mathrm{a}}$ \\
\hline 200 & + & $7.0^{\mathrm{a}}$ \\
\hline 32 & - & $88^{\mathrm{b}}$ \\
\hline 75 & - & $206^{\mathrm{c}}$ \\
\hline 9 & - & $431.3^{\mathrm{d}}$ \\
\hline 17 & - & $403.8^{\mathrm{d}}$ \\
\hline 25 & - & $385^{\mathrm{d}}$ \\
\hline 266 & - & $125^{\mathrm{e}}$ \\
\hline 255 & - & $185^{\mathrm{c}}$ \\
\hline 267 & - & $185^{\mathrm{c}}$ \\
\hline 262 & - & $195^{\mathrm{c}}$ \\
\hline
\end{tabular}

(+), pseudo black chaff present (PBC); (-), pseudo black chaff absent; AUDPC, area under disease progress curve values are means of two replications and means with same letters within the column are not significantly different at $P<0.05$ according to Tukey HSD test.

The $21 \mathrm{BC}_{1} \mathrm{~F}_{1}$ plants that showed susceptibility to stem rust disease had mean AUDPC values ranging from 282.5 to 431.3 and plants 9, 17 and 25 had the highest AUDPC means of 431.3, 403.8 and 385 respectively. All the susceptible parent plants had AUDPC means ranging from 285 to 357.5 except for parent plants 266, 255, 267 and 262 which had low AUDPC means of 125, 185, 185 and 195 respectively (Table 2.).The mean AUDPC values among the plants was significantly different $(\mathrm{P}<0.001)$, but from one replicate to another there was no significant difference $(\mathrm{P}>0.001)$.

\subsection{Stem Rust AUDPC Values ofthe $\mathrm{BC}_{1} \mathrm{~F}_{1}$ Plants and Parents}

The low disease severity on the 115 plants that had the PBC trait, showed the true linkage of the expression to the $S r 2$ gene that slows the rate of infection of plants to stem rust disease [23]. The low mean AUDPC values and low disease severities indicated a high level of resistance to stem rust in the 115 plants with PBC, which is in agreement with the outcomes of [24], where the resistant cultivars had low disease severity and lowest AUDPC values throughout the disease assessment period. There were $104 \mathrm{BC}_{1} \mathrm{~F}_{1}$ plants (Table 1) that lacked the PBC expression but showed resistance to stem rust. These plants had higher mean AUDPC values compared to the plants which expressed the pseudo black chaff. This is an indication that the $S r 2$ gene might be present in a plant interacting with other polygenic genes to bring about resistance but fail to express the PBC trait phenotypically. Plants with mean AUDPC values below 151 showed low disease severity, those with mean AUDPC values above 151 but less than 255 showed moderate severity to stem rust while plants with mean AUDPC values above 255 (Susceptible plants) showed high disease severity which was in agreement with the findings of [25], who found out that there was correspondence between genotypes susceptibility and AUDPC showing that the most susceptible wheat cultivars recorded high AUDPC values.

\section{Conclusion}

This study demonstrated that $\mathrm{BC}_{1} \mathrm{~F}_{1}$ wheat plants received the Adult Plant Resistance (APR) genes for stem rust evidenced by the low disease severity mean scores and this could be useful for wheat improvement as far as resistance to stem rust is concerned.

\section{References}

[1] A. P. Bonjeanand W. J. Angus (2001).The world wheat book: a history of wheat breeding. Andover: Intercept.Excellent Resource for 20th Century Plant Breeding, pp. 1131. ISBN 1-898298-72-6.

[2] M. C. Luo, Z. L. Yang, F. M. You, T. Kawahara, J. G. Waines and J. Dvorak, The structure of wild and domesticated emmer wheat populations, gene flow between them and the site of emmer domestication. Theoretical Applied Genetics, 2007, 114: 947-959.

[3] M. Heun, S. Abbo, S. Lev-Yadun and A. Gopher, A critical review of the protracted domestication model for Near-Eastern founder crops: linear regression, long distance gene flow, archeological and archeobotanical evidence. Journal of Experimental Botany, 2012, 63:4333-4341.

[4] International Starch Institute, Technical memorandum on production of wheat starch. Available online (http://www.starch.dk/isi/starch/tm33www-wheat.htm), 2008, accessed March 2, 2013.

[5] United States Department of Agriculture - Food and Agriculture Service (USDA-FAS), Global agricultural information network: Wheat production in Kenya by year. Available online (http://www.indexmundi.com/agriculture,2012, accessed June 24, 2014.

[6] J. J. Palmer, How to brew. Defenestrative Public Company.ISBN 0-9710579-0-7, 2001, pp 233.

[7] N. E.Borlaug,Sixty two years of fighting hunger: personal recollections. Euphytica, 2007, 157: 287-297.

[8] M. S. Priyamvada and T. Ratan, Durable resistance in wheat.International Journal of Genetics and Molecular Biology, 2011, 3 (8): 108-114. 
[9] R. A. McIntosh, The role of specific genes in breeding for durable stem rust resistance in wheat and triticale. In: Simmonds N. W. and Rajaram S. (eds.), Breeding strategies for resistance to the rusts of wheat CIMMYT, Mexico, D.F.,1988, pp 1-9.

[10] R. F. Park, Stem rust of wheat in Australia. Australian Journal of Agricultural Resource, 2007, 58: 558-566.

[11] R. P.Singh, D. P.Hodson, J.Huerta-Espino, Y.Jin, M.Kinyua, R.Wanyera, P. Njauand R. W. Ward, Current status, likely migration and strategies to mitigate the threatto wheat production from race Ug99 (TTKS) of stem rust pathogen. CAB Reviews.2006, Perspectives in Agriculture, Veterinary Science, Nutrition and Natural Resources, 1: 54.

[12] Z. A. Pretorius, K. W. Pakendorf, G. F. Marais, R. Prins and J. S. Komen, Challenges for sustainable control of cereal rust diseases in South Africa. Australian Journal of Agricultural Research, 2007, 58: 593-601.

[13] Z. A. Pretorius, R. P. Singh, W. W. Wagoire and T. S.Payne, Detection of virulence to wheat stem rust resistance gene Sr31 in Pucciniagraminisf. sp. triticiin Uganda. Plant Diseases, 2000, 84: 203.

[14] R. Wanyera, M. G. Kinyua, Y. Jin and R. P.Singh, The spread of stem rust caused by Pucciniagraminisf. sp. tritici, with virulence on Sr31 in wheat in Eastern Africa. Plant Diseases, 2006, 90: 113.

[15] D. P. Hodson, R. P. Singh and J. M. Dixon, An initial assessment of the potential impact of stem rust (race Ug99) on wheat producing regions of Africa and Asia using GIS. 7th International Wheat Conference, held in November 27 - December2, 2005, at Mar del Plata, Argentina, pp. 142.

[16] R. P.Singh, D. P.Hodson, J.Huerta-Espino, Y.Jin, P.Njau, R.Wanyera, S. Herrera-Foessel and R. W. Ward, Will stem rust destroy the world's wheat crop? Advances in Agronomy, 2008, 98: 272-309.

[17] R. A. McIntosh, Y. Yamazaki, K. M. Devos, J. Dubcovsky, W. J. Rodgers and R. Appels, Catalogue of gene symbols for wheat. In the $10^{\text {th }}$ International Wheat Genetics Symposium proceedings, held from $1^{\text {st }}$ to $6^{\text {th }}$ September, 2003, in Paestum, Rome, pp 77-79.

[18] Export Processing Zone Authority (EPZ), Grain production in Kenya, 2005, pp 6-7.

[19] R. A. McIntosh, C. R. Wellings and R. F.Park, Wheat Rusts: An Atlas of resistant genes. CSIRO, Australia,1995, pp 3-7.

[20] P. N. Njau, Y. Jin, J. Huerto -Espino, B. Keller and R. P.Singh, Identification and evaluation of sources of resistance to stem rust race Ug99 in wheat. Plant Diseases, 2010, 94:413-419.

[21] A. P. Roelfs, R. P. Singh and P. P. Saari, Rust diseases of wheat: Concepts and methods of disease management. CIMMYT, Mexico, 1992, DF.

[22] SAS Institute, SAS procedure for personal computers. Version 9.1 SAS Institute. Cary, North Carolina, 2001, USA.

[23] S. Bhavani., R.P. Singh, O. Argillier, J. Huerta-Espino, S. Singh and P. Njau, Mapping of durable adult plant stem rust resistance in six CIMMYT wheats to Ug99 group of races: Technical Workshop held from $13^{\text {th }}$ to $16^{\text {th }}$ June, 2011, in St Paul, Minnesota, U.S.A., pp 11-13.

[24] T. Tolessa, F. Chemada and W. Getaneh, Evaluation of wheat cultivars for slow rusting resistance in Guji Zone Southern Oromia, Ethiopia. African Journal of Agricultural Research, 2014, 9 (46): 3388- 3392.

[25] M. Paraschivu, O. Cotuna and M. M. Paraschivu, The use of area under disease progress curve (AUDPC) to assess the epidemics of Septoriatritici in winter wheat. Research Journal of Agricultural Science, 2013, 45(1): 194-199. 